\title{
Corporate financial restructuring in Asia: implications for financial stability ${ }^{1}$
}

\begin{abstract}
Corporate financial fragility preceding the Asian financial crisis heightened vulnerabilities. Many countries in the region undertook significant corporate financial restructuring after the crisis, with some countries bouncing back much faster than others. These sounder corporate financial practices bode well for financial stability.
\end{abstract}

JEL classification: G32, G38.

The 10th anniversary of the outbreak of the Asian crisis has been accompanied by numerous retrospectives on the causes of the crisis as well as the subsequent performance of the affected economies. Many regard the crisis as having been the consequence of fundamental economic problems greatly exacerbated by financial vulnerabilities. ${ }^{2}$ The situation of the East Asian economies has improved considerably since then. Trade balances, foreign currency reserves, corporate governance, the depth of financial markets and quality of government regulation, as well as various indicators of public sector health, are now stronger than before in the five most affected countries Indonesia, Korea, Malaysia, Thailand and the Philippines.

This special feature focuses on the dimension of corporate finance as an important factor underlying Asia's financial crisis and recovery. Problems in the corporate sector were in many respects mirrored in the financial sector. To the extent that the corporate sector was fragile - over-leveraged, unprofitable - the assets of the banking sector were more likely to be poor. It is therefore instructive from the point of view of financial stability to examine the health of the corporate sector in East Asian economies 10 years after the crisis swept through the region.

1 The views expressed in this article are those of the author and do not necessarily reflect those of the BIS. The author would like to thank Claudio Borio, Már Gudmundsson, Robert McCauley, Frank Packer, Eli Remolona and Philip Wooldridge for helpful comments and suggestions.

2 For example, see Corsetti et al (1998), Pomerleano (1998), Mishkin (2000), Radelet and Sachs (1998) and Geithner (2007). On recent improvements since the crisis, see Standard \& Poor's (2006), Moody's (2007) and Truman (2007). 
The special feature is organised as follows. The first section presents quantitative evidence of corporate financial fragility in East Asia, both before and after the crisis. The second explores reasons for the improvement in corporate financial conditions, with an emphasis on structural reforms. The third section concludes, offering a few general policy recommendations to strengthen corporate financial practices further.

\section{Assessing corporate financial soundness in Asia}

\section{Before the crisis}

Quantitative financial indicators assessing the financial soundness of publicly listed firms - including ratios measuring performance, profitability and coverage, liquidity, and solvency - suggest considerable corporate financial fragility preceded the wave of financial crises in East Asia. High levels of capital expenditures combined with poor profitability were reflected in low and declining returns on equity and capital (Pomerleano (2007)). This special feature focuses on two illustrative financial indicators: leverage and the capacity to service debt (see discussion of data in Box 1).

Benchmarking Asian crisis countries against corporate financial data in Hong Kong SAR and developed countries reveals that corporate leverage was quite high prior to the crisis in at least two of the five of the crisis-affected countries (Graph 1). In 1996 the two most leveraged countries - Korea and Thailand - had median debt-to-book-equity ratios for listed firms of $355 \%$ and
Considerable corporate financial fragility preceding the crisis

Corporate leverage was high in Thailand and Korea ...

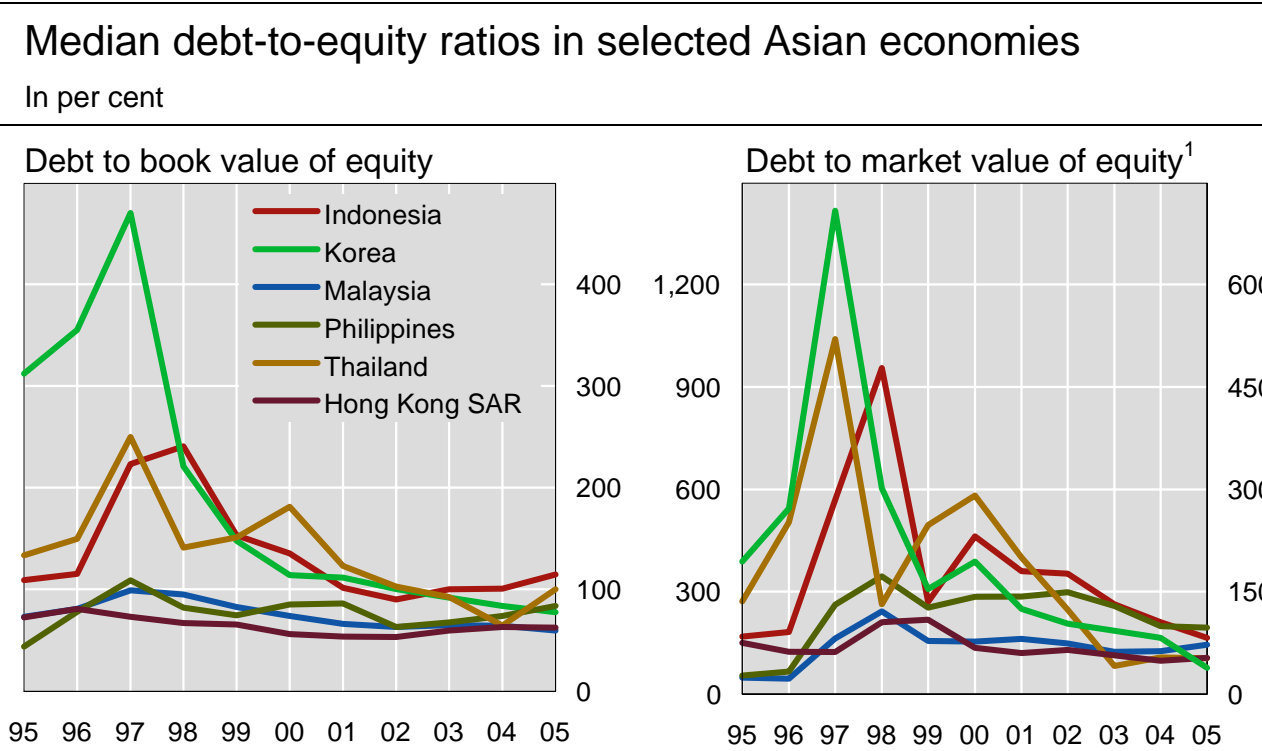

Comparative developed country figures for 1996 (2005) are: in the left-hand panel, France, 142 (165); Germany, 216 (131); Japan, 166 (114); Netherlands, 122 (126); Sweden, 122 (110); United Kingdom, 109 (101); United States, 127 (124); in the right-hand panel, France, 104 (82); Germany, 128 (69); Japan, 91 (92); Netherlands, 45 (59); Sweden, 56 (42); United Kingdom, 48 (45); United States, 37 (43).

1 For Korea, left-hand scale.

Source: Author's calculations using Worldscope data. 


\section{Box 1: Leverage measures and data sources}

Firm-level data for the study come from the Worldscope database. The primary sample consists of firms from emerging markets for which data are available in Worldscope for the years 1995-2005. The emerging markets covered are Hong Kong SAR, Indonesia, Korea, Malaysia, the Philippines and Thailand. Comparisons are on occasion made with firms in the developed countries of France, Germany, Japan, the Netherlands, Sweden, the United Kingdom and the United States.

The companies selected for the analysis are general manufacturing firms, as well as extractive industries and utilities for which financial statements are available for the period 1995-2005. Traditional financial analysis employs several ratios to assess financial soundness, including ratios measuring performance, profitability and coverage, and liquidity and solvency. The analysis uses median values because they reveal more information than averages across firms in the sample. However, a number of important caveats are warranted.

First, as transparency and reporting have improved, Worldscope has extended the number of firms covered. For instance, in Malaysia the sample of firms increases from 88 in 1995 to 746 in 2005. ${ }^{(1)}$ Thus the ratios might reflect not only within-firm trends in leverage and profitability but also trends resulting from changes in the composition of the sample. Second, the sample consists of publicly listed firms only, which may present a limited picture of corporate financial fragility in countries where unlisted firms account for a large share of economic activity. Third, the financial ratios used to measure risk do not capture off-balance sheet risks such as foreign exchange risk exposures and corporate risk management practices. Fourth, cross-border comparisons require additional care, given the differences in accounting conventions and local financial systems, despite efforts to adjust the data to international norms. Finally, the leverage ratios are likely to be distorted by the abrupt changes in exchange rates after the crisis. Unfortunately, we do not have data on the currency denomination of debt to make appropriate adjustments.

The two key ratios used in the main body of the analysis are:

Interest coverage ratio (ICR). Adjusted earnings from continuing operations before interest, taxes, depreciation and amortisation divided by gross interest incurred before subtracting capitalised interest and interest income.

Debt to equity. Long-term debt plus current maturities, commercial paper and other short-term borrowings divided by book (or market) value of shareholders' equity (including preferred stock) plus minority interest.

Interest coverage and leverage measures tend to be highly correlated with the credit ratings awarded by the major international rating agencies (see the table).

\section{Standard \& Poor's US corporate ratings and measures of debt burden}

Three-year median (2002-04)

\begin{tabular}{|l|r|r|r|r|r|r|r|}
\hline Indicator & AAA & AA & A & BBB & BB & B & CCC \\
$\begin{array}{l}\text { EBITDA interest coverage (x) } \\
\begin{array}{l}\text { Ratio of total debt to total debt plus } \\
\text { equity (per cent) }\end{array}\end{array}$ & 25.5 & 24.6 & 10.2 & 6.5 & 3.5 & 1.9 & 0.9 \\
\hline
\end{tabular}

EBITDA interest coverage adds depreciation and amortisation back to the numerator. The leverage measure reported is long-term debt plus current maturities, commercial paper and other short-term borrowings divided by long-term debt plus current maturities, commercial paper and other short-term borrowings plus shareholders' equity (including preferred stock) plus minority interest.

Source: Standard \& Poor's.

Table A

(1) For Indonesia, the corresponding numbers are 97 and 227, for Korea 94 and 319, for the Philippines 38 and 85 , for Thailand 15 and 49, and for Hong Kong SAR 89 and 606. 


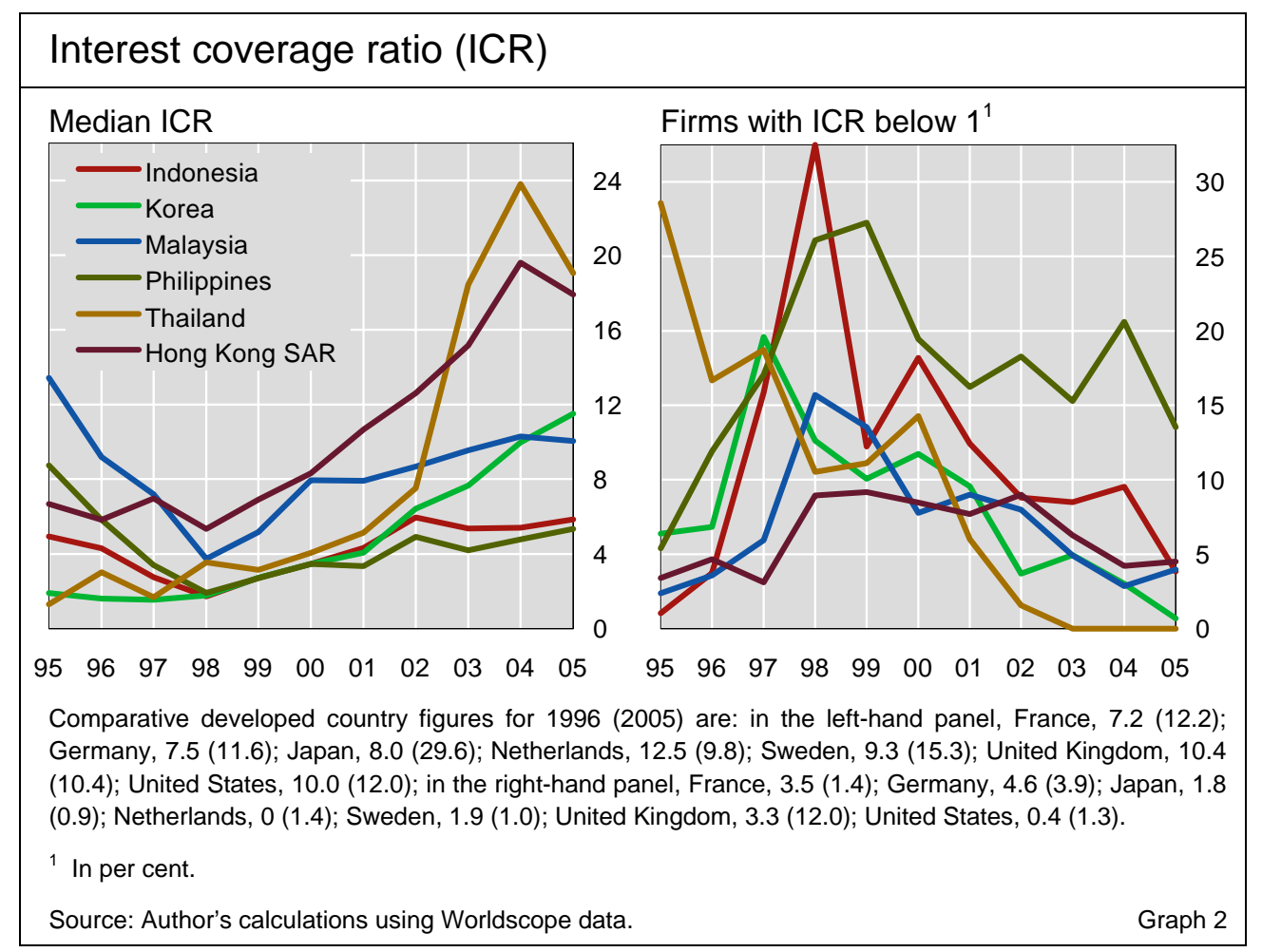

$150 \%$, respectively. ${ }^{3}$ By contrast, the corresponding median leverage ratios were $142 \%$ in France, 109\% in the United Kingdom, 127\% in the United States and $80 \%$ in Hong Kong SAR. Using market values of equity yields more pronounced results: Korea and Thailand had median debt-to-market value of equity ratios of $543 \%$ and $251 \%$, respectively, well above the values presented for any of the comparator countries. High levels of leverage were likely to have been taken on in large part to fund rapid growth in fixed assets. For example, in 1996 and 1997, respectively, net growth of plant and equipment was $28 \%$ and $30 \%$ in Korea, and $34 \%$ and $45 \%$ in Thailand.

The capacity to service this debt for three of the affected countries was already relatively depressed prior to the crisis. The interest coverage ratio (ICR) is calculated as the ratio of cash flows generated from operations to gross interest charges. In 1996 the median ICR of listed firms was 4.3 for Indonesia, 1.6 for Korea and 3.0 for Thailand, inordinately low compared to other countries (Graph 2). For instance, the comparable statistics were 5.8 for Hong Kong SAR, 7.2 for France, 7.5 for Germany, 8.0 for Japan, 10.4 for the United Kingdom and 10.0 for the United States. The right-hand panel of Graph 2 also shows that a significant percentage of firms in some countries in East Asia were unable to generate adequate cash flow to service debt even before the crisis. Nearly $20 \%$ of listed firms in Thailand had an interest coverage ratio below 1 and faced a risk of default in 1996. Of course, these percentages

3 The leverage measures rise to even higher levels in 1997, though we cannot measure the extent to which this was due to the onset of the crisis in the second half of 1997, reflecting among other things the increase in the burden of foreign currency debt due to domestic currency depreciation. The leverage measures also rose considerably in 1997 in the other three crisis countries, Indonesia, Malaysia and the Philippines.

... while interest coverage was low in Thailand, Korea and Indonesia 
Corporate finances improved significantly after the crisis

increased significantly for both Thailand and other Asian countries with the onset of the crisis.

\section{After the crisis}

The situation improved significantly after the crisis. Beginning in 1998, leverage began to fall significantly for Korea and Thailand, with book (market) leverage dropping to $77 \%(76 \%)$ in Korea and $99 \%(52 \%)$ in Thailand by 2005 , well below pre-crisis levels. At the same time, interest coverage ratios improved markedly to above pre-crisis levels in all of the crisis countries except the Philippines (Graphs 1 and 2). By 2005, much smaller percentages of firms in East Asian countries had an interest coverage ratio below 1 . Only in the Philippines was the percentage of firms unable to cover their debt service still relatively high, at $13.5 \%$.

Additional evidence is provided by a composite corporate financial strength score for each firm in the sample. Traditional financial analysis is limited by the use of ratios measuring profitability, liquidity and solvency, without offering a comprehensive score or rating to assess overall financial strength. Altman (1968) extends ratio analysis using multiple discriminant analysis (MDA) to develop the Z-score model. Altman et al (1995) modify the $Z$-score model to assess firms in emerging markets, and calculate emerging market Z-scores (EMS; Box 2).

Graph 3 shows the results of applying the EMS to the corporate sector in East Asia over the sample period. By 2005, the median Z-score for Korean, Malaysian and Thai listed firms had all increased significantly to beyond precrisis levels, and were comparable to those of the Hong Kong SAR and developed country sample. The share of firms with Z-scores over 6.4 - which

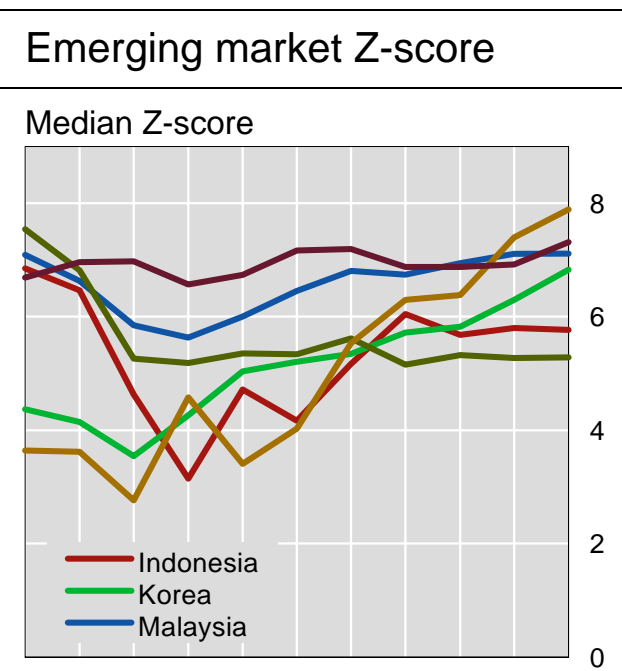

$\begin{array}{lllllllllll}95 & 96 & 97 & 98 & 99 & 00 & 01 & 02 & 03 & 04 & 05\end{array}$

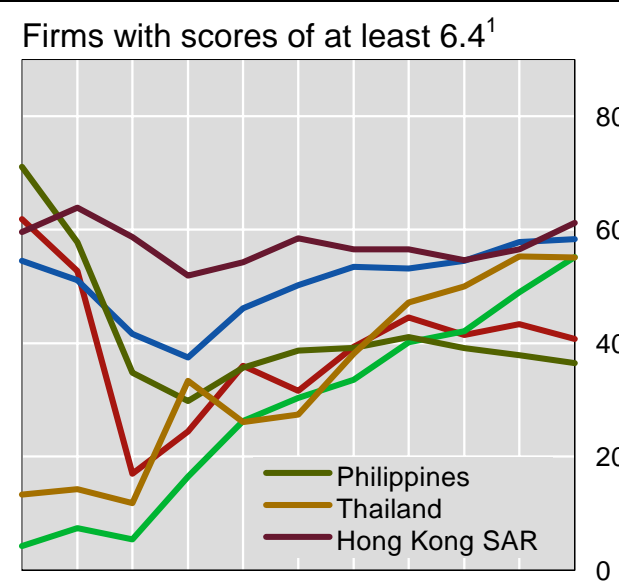

$\begin{array}{lllllllllll}95 & 96 & 97 & 98 & 99 & 00 & 01 & 02 & 03 & 04 & 05\end{array}$

Comparative developed country figures for 1996 (2005) are: in the left-hand panel, France, 5.9 (5.0); Germany, 5.9 (6.1); Japan, 5.6 (6.4); Netherlands, 6.7 (6.1); Sweden, 6.7 (6.7); United Kingdom, 6.4 (5.8); United States, 6.8 (6.9); in the right-hand panel, France, 36.4 (27.4); Germany, 37.5 (44.8); Japan, 37.6 (49.5); Netherlands, 66.7 (45.8); Sweden, 55.0 (56.6); United Kingdom, 49.1 (41.7); United States, 57.7 (55.3)

1 In per cent; 6.4 corresponds to the score of A- rated US corporates using the model (Altman et al (1995)).

Source: Author's calculations using Worldscope data. Graph 3 
corresponds to the score for US corporations rated A- by credit rating agencies - rose to well over one half in all three countries as well (in 1996, only $7.4 \%$ and $14.3 \%$ of the listed firms in Korea and Thailand, respectively, reached an equivalent score). It should be noted, however, that in Indonesia and the Philippines, median Z-scores and the proportion of firms with high scores remain below pre-crisis levels.

Improvements in the liability structure of the corporate sector (not captured in the above-mentioned EMS) are probably also lending support to sounder corporate finances in a number of Asian countries. Historically, the structure of domestic private sector liabilities had been characterised by short maturities and exposure to foreign currency-denominated debt. The recent development of local currency corporate bond markets in East Asia has helped to reduce vulnerabilities in the corporate sector. Malaysia, Korea and Thailand (with $52 \%, 18 \%$ and $25 \%$ of total bonds outstanding, respectively) have made notable progress in developing the corporate bond markets, and the Korean corporate bond market has become less dependent on bank guarantees (CGFS (2007)).

The development of domestic corporate bond markets enhances financial stability through several channels. First, it reduces the risks of foreign exchange mismatch. Second, the disclosure requirements for bond issuance contribute to a general improvement in the quality of corporate reporting. Third, corporate bond markets introduce a transparent market-based process for assessing corporate credit risks. Finally, corporate bond markets disperse the concentration of risk away from the local banking system. A good example is the corporate bond market in Malaysia, which hardly existed in the late 1980s. Once regulatory impediments were relaxed and the approval process was
Local currency corporate bond markets in East Asia help to reduce vulnerabilities

\section{Box 2: The emerging market Z-score model}

Traditional financial analysis employs ratios measuring profitability, liquidity and solvency to assess the likelihood of financial distress for corporate borrowers. Altman (1968) extends ratio analysis using multiple discriminant analysis (MDA), which classifies an observation into one of several a priori groupings dependent on the observation's individual characteristics. Altman uses MDA to predict bankruptcy in the US setting. It is rarely possible to build a similar country-specific model for corporations in emerging markets because of their lack of credit histories. To deal with this problem, Altman et al (1995) modify the original Altman Z-score model to create the emerging market (EM) model used in this analysis. The model uses the ratio of working capital to total assets, ratio of retained earnings to total assets, ratio of operating income to total assets, and ratio of book value equity to total liabilities.

The discriminant function is as follows:

EM Z-score $=6.56 \times 1+3.26 \times 2+6.72 \times 3+1.05 \times 4+3.25$

where $\mathrm{X} 1=$ working capital to total assets; $\mathrm{X} 2=$ retained earnings to total assets; $\mathrm{X} 3=$ operating income to total assets; and $X 4=$ book value equity to total liabilities. Based on the credit ratings of major credit rating agencies for US corporates and the corresponding EM-Z-scores, Altman et al (1995) note that an EM Z-score of 5.65 corresponds to a rating of BBB- for US corporates, 6.4 to $A-, 7.0$ to AA-, etc. Nonetheless, the authors also remark that upward and downward adjustments based on special features of the bond industry, vulnerabilities due to foreign currency denomination of debt, and other factors would be necessary before assigning bond-rating equivalents. 


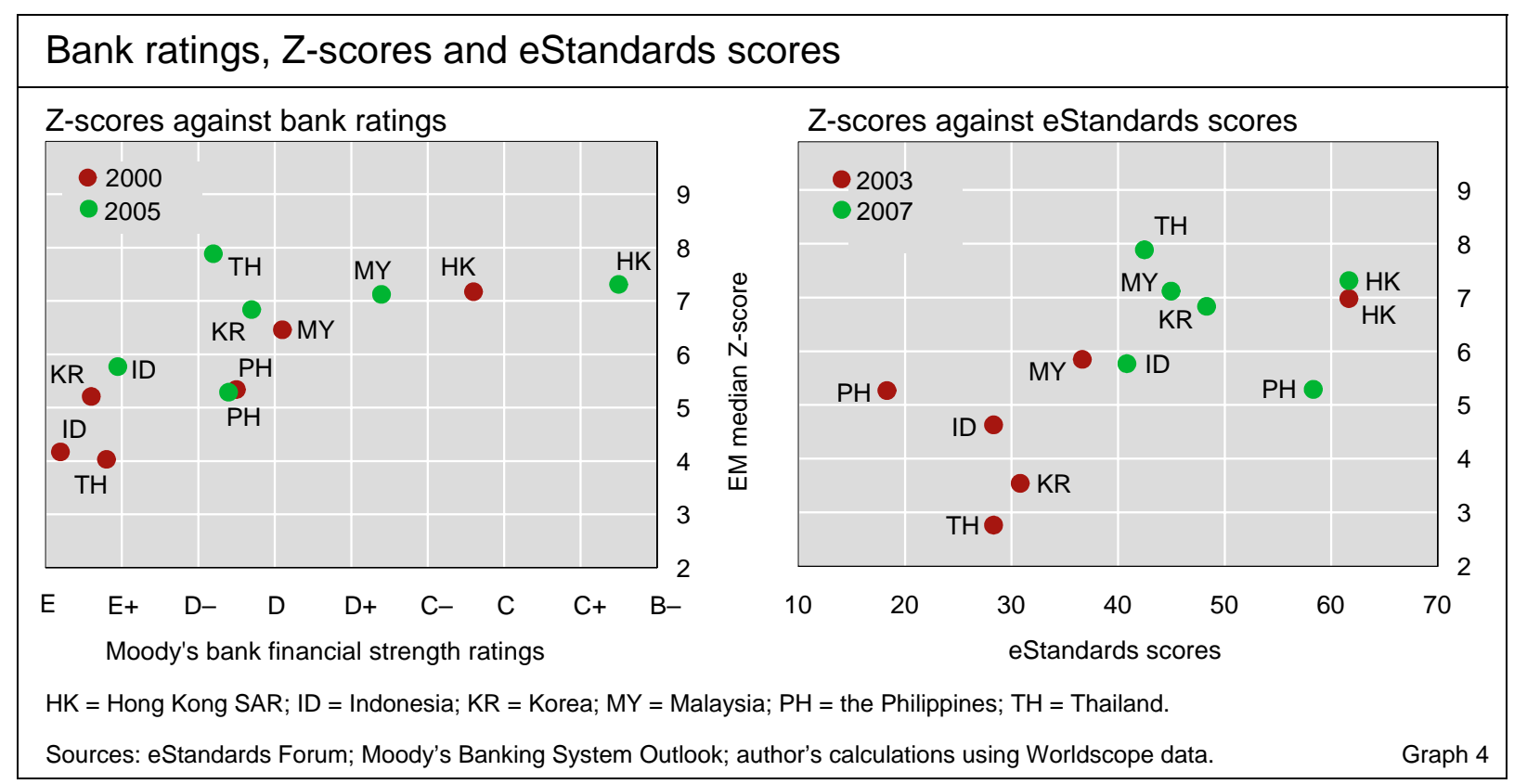

Improvements in corporate finances are to some extent mirrored in the banking system
Increased leverage reflecting both cyclical and structural trends streamlined, the corporate bond market grew from 21\% of GDP in 1997 to $38 \%$ of GDP by 2005 (see the paper by Ibrahim and Wong in BIS (2006)) and private debt securities emerged as the largest source of private sector financing.

In summary, leverage measures, Z-score analysis and examination of the changes in liability structures offer clear evidence of sounder corporate financing practices in a significant number of the Asian crisis countries. Of the three countries with the highest leverage measures prior to the crisis, Thailand and Korea offer the clearest signs of improvement in corporate financial conditions. Malaysia, though not particularly highly leveraged prior to the crisis, has shown noticeable improvement in the composite measures of corporate financial health. The listed firms in the Philippines and Indonesia appear to have achieved a more modest improvement in corporate finances, if any.

The improvements in corporate finances are to some extent mirrored in the banking system. Turner (2006) reports that the Asian crisis stimulated major structural changes in the banking systems in some countries, and there is good evidence of stronger performance. Yet he concludes that there are still several signs of inefficiency and poor risk management practices. Mohanty (2006) concludes as well that, over the past decade, Asian banks have made considerable progress in addressing their past vulnerabilities. A more diversified loan portfolio, reduced currency mismatches and improved financial health have all played a role in the recent revival of bank credit in Asia. The left-hand panel of Graph 4 depicts a concurrent improvement over 2000 in the median of Moody's bank financial strength ratings and the median Z-scores for Indonesia, Korea, Malaysia and Thailand.

\section{What explains the improvements in corporate finances?}

While the reasons for high leverage before the crisis were multidimensional and reflected both cyclical and structural trends, we focus on the high levels of 
international capital flows and the opaque framework of ties between the corporate, banking and government sectors.

International capital flows were particularly important. Capital accounts were liberalised in Korea, with the opening of the short-term capital account, and Thailand set up the Bangkok International Banking Facility scheme. The commitment of many governments to fixed or virtually-fixed exchange rates in the region encouraged foreign currency borrowing. New bank lending was especially strong. Net flows of private debt to developing countries rose sharply in the 1990s, reflecting an increase in gross financing through syndicated bank lending, which set records in 1996.

The implicit role of the government in support of industry probably contributed to the high levels of leverage in a number of countries. Wade (1990) argues that the predominant approach to economic policymaking in the 1950s and 1960s in East Asia stressed the links among corporations, banks and governments and assigned a substantial role to the state in "repairing" perceived market failures. Further, East Asian economies distrusted marketbased intermediation and preferred to control the intermediation of savings from the public through banks. Although Korea transferred bank ownership to the private sector in 1981, the practice of government intervention, such as the appointment of bank CEOs by the Ministry of Finance and Economy, selective credit policies for heavy and chemical industries and indirect controls over the allocation of bank credit, continued throughout the 1980s and early 1990s (Hahm (2005)).

The lack of financial discipline was also attributable to the intricate webs of cross and pyramidal ownership structures of many Asian corporations. One of the biggest challenges in assessing the soundness of the corporate sector was the lack of accurate consolidated financial statements. For instance, Korean corporates did not consolidate their financial statements, and the reporting of standalone entities did not capture the extent of cross shareholdings and cross guarantees. The lack of transparency and disclosure on the composition of corporate liabilities and financial assets can curtail the ability of market participants to monitor risks (FSF (2000)).

\section{Structural reforms}

The lower levels of leverage that prevailed in many countries after the crisis were driven by fundamental demand and supply factors, but also by sounder corporate and banking financial practices. As for fundamentals, there has been a marked fall in the investment rate. The correlation between the ratio of investment to GDP and lagged GDP growth - a simple "accelerator" relationship - fell sharply following the crisis (Kramer (2006)). The decline was especially large in Indonesia, Malaysia and Thailand, and the average investment rate, at around $25 \%$ of GDP during 2000-04, remains significantly below the pre-crisis average of $34 \%$ of GDP (World Bank (2006)).

Equally, changes in corporate financial practices contributed to the decline in leverage. Following the crisis in the late 1990s, corporates adopted sounder practices, divesting non-core business, reducing capital investment and using internally generated cash to reduce debt. Meanwhile, chastised domestic and

A decline in leverage is driven by demand and supply factors ... 
Asia is making progress in adhering to international standards and codes foreign banks showed less tolerance for risky lending, and reduced corporate exposures, while focusing on consumer lending.

Decisive reforms undertaken by East Asian governments supported the improvement in corporate financial practices. East Asian financial infrastructure suffered from systemic weaknesses: poor corporate governance, weak auditing and accounting standards, and inadequate bankruptcy laws. Therefore the response to the crisis was multifaceted, covering a range of remedies.

One particular focal point for improvement was the bankruptcy resolution process, which required an effective insolvency regime and out-of-court arrangements, and all the countries took measures to that end. Korea and Malaysia - countries with a strong culture of creditor rights and legal systems for insolvency - reached the most effective out-of-court resolutions using bankruptcy as a deterrent.

In Korea, a critical component of the entire corporate restructuring process has been the introduction of international accounting standards. Korean corporates were mandated to adopt international accounting standards by 2000, leading to improved disclosure and reporting requirements for public companies. Korea also adopted regulatory and tax incentives to put pressure on borrowers and banks alike and support the restructuring. The former chairman of a corporate restructuring committee during the crisis in Korea has opined that forcing supervised firms (and particularly banks) to be audited according to international accounting standards was the single most important policy initiative (World Bank (2005)).

The above case is an example of a more general point: financial systems function better when they are supported by a strong financial infrastructure. There is broad agreement that adopting the standards of international best practice offers countries the best opportunity for stability. The standards and codes initiative was launched by the FSF in 1999 to promote greater financial stability, at both the domestic and international levels, through the development, dissemination, adoption and implementation of international standards and codes. Its objective was to assist countries in strengthening their economic institutions and informing market participants. Twelve Key Standards for Sound Financial Systems were designated as warranting priority implementation. These standards relate to policy transparency, financial sector regulation and supervision, and market integrity.

How much progress has East Asia made in adhering to international norms? Though many measures of progress in implementing standards developed in the policy community are not meant for public dissemination, ${ }^{4}$ there are some relevant measures in the public domain. Since 2000 , the eStandards Forum has been monitoring the progress of 83 countries in adopting and implementing the 12 international standards and codes identified by the FSF as warranting expeditious implementation. eStandards'

4 Reports on the Observance of Standards and Codes (ROSCs) covering financial sector standards are usually prepared in the context of the IMF and World Bank Financial Sector Assessment Program. The assessments are highly qualitative and published only occasionally at the request of the member country. Therefore, the ROSCs do not allow an assessment of the extent of progress. As a result, this special feature relies on only public domain sources. 


\begin{tabular}{|l|r|r|}
\hline \multicolumn{2}{|c|}{ Compliance scores for East Asian economies, 2003-07 } \\
\hline & $\begin{array}{c}\text { 1 January 2003 starting } \\
\text { score }\end{array}$ & $\begin{array}{c}\text { 31 January 2007 ending } \\
\text { score }\end{array}$ \\
\hline Hong Kong SAR & 62 & 62 \\
Singapore & 31 & 56 \\
Philippines & 18 & 58 \\
Korea & 31 & 48 \\
Malaysia & 37 & 45 \\
Thailand & 28 & 43 \\
Indonesia & 28 & 42 \\
China & 11 & 24 \\
\hline Memo: Five developed countries & & \\
United Kingdom & 68 & 78 \\
Australia & 74 & 73 \\
France & 56 & 73 \\
Netherlands & 40 & 73 \\
United States & 75 & 70 \\
\hline Source: eStandards Forum. & \multicolumn{2}{|c}{} \\
\hline
\end{tabular}

assessments, which rely exclusively on publicly available information, examine the rules and regulations, enforcement and the political and regulatory environment, rank the progress towards full compliance and assign a score between 0 and 100 .

To be sure, the ratings and assessments produced by eStandards need to be interpreted with caution. As mentioned, eStandards' assessments rely solely on publicly available information. Asian economies, as a group, have not been actively participating in the IMF/World Bank Financial Sector Assessment Program. Therefore, low ratings might simply reflect far less publicly available information. With this caveat in mind, it is important to focus more on the trends than the absolute scores.

The average scores across East Asian countries shows that they have made considerable progress since 2003, when the first scores become available (Table 1). With the exception of the highest-ranking country, which has maintained its score, all of the eight sampled East Asian countries have improved their scores. Within the individual score components, while considerable improvement is evident in the macro area - fiscal and monetary transparency and discipline - slower progress is noted in the implementation of skills-intensive areas such as accounting and auditing, insolvency and governance.

The widespread nature of the improvement suggests that the linkage with improvements in corporate finances is not clear-cut. The right-hand panel of Graph 4 documents a concurrent improvement since 2003 in the median of corporate Z-scores and eStandards scores for Korea, Malaysia and Thailand. On the other hand, there have also been marked improvements in the compliance scores for the Philippines and Indonesia, countries for which, as 
mentioned above, an improvement in corporate financial conditions relative to the period before the crisis is not as evident.

\section{Conclusions}

Further efforts to improve financial practices and infrastructure are essential
There has been a marked transformation in financial practices in East Asia, leading to more robust corporate sector. While all the countries in the region appear to be in the process of restructuring in one dimension or another, Korea, Malaysia and Thailand have made the most progress, judging by their corporate financial indicators. Further efforts to improve corporate financial practices, banking systems and financial infrastructure are essential to ensure that future increases in leverage take place on a sounder footing.

In particular, there is a need for increased transparency and disclosure of risks to the market, because early detection of vulnerabilities can lead to earlier intervention and thus crisis prevention. Officials responsible for economic policy need to develop means of obtaining adequate information on the financial soundness of the corporate sector, as well as ensuring that good quality information is made available for market participants to monitor the risks. Policymakers might consider methods of boosting the analysis and reporting of those corporate risks, such as excessive external borrowing or currency mismatches, whose disclosure would be in the public interest.

\section{References}

Altman, E (1968): "Financial ratios, discriminant analysis, and the prediction of corporate bankruptcy", Journal of Finance, vol 23, September, pp 589-609.

Altman, E, J Hartzell and M Peck (1995): "Emerging markets corporate bonds: a scoring system", Salomon Brothers, New York.

Bank for International Settlements (2006): "Developing corporate bond markets in Asia", BIS Papers, no 26, February.

Committee on the Global Financial System (2007): "Financial stability and local currency bond markets", CGFS Papers, no 28, June.

Corsetti, G, P Pesenti and N Roubini (1998): "What caused the Asian currency and financial crisis? Part I: A macroeconomic overview", NBER Working Paper 6833, National Bureau of Economic Research, Cambridge, Mass, December.

eStandards Forum: http://www.estandardsforum.com/servlet/home.

Financial Stability Forum (2000): Working group on capital flows, April.

Geithner, T F (2007): "Reflections on the Asian financial crises", remarks at the Trends in Asian Financial Sectors Conference, Federal Reserve Bank of San Francisco, 20 June.

Hahm, J (2005): "The Korean model of corporate governance: issues and lessons in reform of bank governance", HGCY Working Paper, 05-01, Hills Governance Center, Yonsei University, Seoul. 
Kramer, C (2006): "Asia's investment puzzle", Finance and Development 43 (2), June.

Mishkin, F S (2000): "Lessons from the Asian crisis", NBER Working Paper 7102, National Bureau of Economic Research, Cambridge, Mass, August.

Mohanty, M S (2006): "Banks and financial intermediation in Asia: what has changed?", paper prepared for the conference volume on the Tokyo roundtable on capital market reforms in Asia, 7-8 October.

Moody's Investors Service (2007): "The Asian crisis ten years later: what we know, what we think we know and what we do not know", Moody's International Policy Perspectives, May.

Pomerleano, M (1998): "The East Asia crisis and corporate finances: the untold micro story", Emerging Markets Quarterly (winter).

___ (2007): Three essays on financial crisis, Harvard University.

Radelet, S and J Sachs (1998): "The East Asian financial crisis: diagnosis, remedies, prospects", Brookings Paper 28 (1), pp 1-74.

Standard \& Poor's Asia (2006): "1997 retrospective: repeat of 1997 crisis unlikely, but high leverage a worry", September.

Turner, P (2006): "Banking systems in East Asia: ten years later", paper presented at the Asian Economic Policy Review conference on "Ten years after the Asian crisis: what have we learned and not learned", Tokyo, October.

Truman, E M (2007): "Asia's economic outlook", remarks at the conference Trends in Asian financial sectors, part of the conference and seminar series "The Asian financial crisis revisited: challenges over the next decade", held at the Federal Reserve Bank of San Francisco, June.

Wade, R (1990): Governing the market: economic theory and the role of government in East Asian industrialization, Princeton University Press.

World Bank (2005): Corporate restructuring: lessons from experience, M Pomerleano and W Shaw, April.

(2006): East Asian finance - the road to robust markets. 